第 43 回 獣医疫学会学術集会

シンポジウム“蚊が媒介する感染症一デング熱を中心に一”

厚生労働省の蚊媒介感染症に関する対応について

福島和子*

厚生労働省健康局結核感染症課 ${ }^{1}$

\title{
Response to Mosquito-borne Diseases by Ministry of Health, Labour and Welfare of Japan
}

\author{
Kazuko FUKUSHIMA* \\ Division of Tuberculosis and Infectious Diseases Control, Health Service Bureau, \\ Ministry of Health, Labour and Welfare, Japan
}

\begin{abstract}
Summary
In Japan, infectious diseases including mosquito-borne diseases are controlled based on the Infectious Disease Control Act (April 1999) which allows public health authorities to take various control measures against the designated infectious diseases. These measures include mandatory notification by physicians, active surveillance of cases and vector-control program etc. Under the Infectious Diseases Control Act, approximately 10 mosquito-borne diseases are designated; such as malaria, dengue fever, chikungunya fever. Every year, a number of imported cases of these mosquito-borne diseases have been reported. However, as autochthonous cases, we only have less than 10 cases of Japanese encephalitis annually in these years due to the effective implementation of vaccination.

Meanwhile, at the end of August 2014, an autochthonous case of dengue fever was confirmed for the first time in the past 70 years. The patient never travelled abroad, and was considered to be infected with dengue virus in Yoyogi Park located in the center of Tokyo based on the activity history and other evidence. This was followed by the report of approximately 160 autochthonous cases by the end of October, and most of the patients had visited Yoyogi Park or its adjacent areas. Through the response to this dengue outbreak in 2014, it was revealed that the knowledge and experience in mosquito control had been weakened or even lost among Japanese public health authorities. To solve this problem and to promote mosquito-control measures, in April 2015, Ministry of Health, Labour \& Welfare announced the "Special Guidance on Mosquito-borne Diseases" which identifies the roles to be played by each stakeholder including the Government, prefectural and municipal governments, physicians/medical institutes and the general public. It is expected that mosquito-borne disease control will be further enhanced by active promotion of this Guidance.
\end{abstract}

連絡先 : 福島和子*

厚生労働省医薬食品局食品安全部監視安全課

干100-8916 東京都千代田区霞が関 1-2-2

Tel : 03-3595-2337; Fax : 03-3503-7964

E-mail : fukushima-kazuko@mhlw.go.jp

${ }^{1}$ 所属は講演当時のもの

“本稿は筆者個人の見解を示すものであって, 筆者 の所属する組織の公式見解を代表するものではあ

りません

\section{1. 感染症に関する法律の変遷}

我が国では，蚊が媒介する感染症（蚊媒介感染症）も含 め, 感染症については, 1999 年 4 月に施行された「感染 症の予防及び感染症の患者に対する医療に関する法律（感 染症法)」に基づいて, 種々の対応が取られている。感染 症法は施行後も, 1999 年以降, 米国で流行しているウエ ストナイル熱や， 2003 年に世界的に大きな注目を集めた 重症急性呼吸器症候群 (SARS) のアウトブレイク等の問 題を受けて, 随時, 法改正や関連する規制の整備を行い, 
対応の強化を図ってきており，直近では，昨年 11 月に, 患者や医療機関に血液検体の提供を要請できる内容などを 含む法改正が行われたところである。

1999 年 4 月以前は, 1897 （明治 30）年に制定された伝 染病予防法により，感染症対策が取られていた。コレラ， 赤痢, 腸チフス, パラチフス, 天然痘などに加え, 蚊媒介 感染症としては日本脳炎が法定伝染病に指定され，医師が これら法定伝染病の患者を診断した場合は, 直ちに保健所 長に届出るとともに, 患者宅の消毒等を指示することとさ れていた。また, マラリア, フィラリア病, 黄熱等を含む その他の感染症を診断した際も, 24 時間以内に保健所長 に届出ることとされていた。

さらに, 伝染病を媒介しうる鼠族や昆虫については, 都 道府県は駆除計画を策定し, 市町村への駆除の指導や必要 な措置を講じるほか, 伝染病の流行時には, 地域を特定し て, 市町村に対して鼠族・昆虫の駆除を命じることができ ることとされていた。

一方, 市町村は, 鼠族・昆虫の駆除に必要な器具や薬品 等の整備を行い, 住民に駆除用の薬品を配布して使い方の 指導を行うほか, 自治会や婦人会, 青年団等, 地域の組織 を活用して，駆除の実施を推進する役割を担っていた。ま た, 道路, 公園, 墓地, 池, 沼, 溝など, 住民の自主的な 活動によっては駆除が期待されない公的な場所の駆除に当 たらせるため, 人口 3 万人ごとに一班を目安に, 衛生昆虫 防除の専門部署である「衛生班」を組織するなどして, 官 民の取組をうまく噛み合わせて，これら衛生昆虫の防除が 円滑に行われるよう調整役を果たしていた。昭和 30 年代 の各自治体の広報誌を見ると, 蚊の駆除について住民に協 力を呼びかける記事が大きく取り上げられており，官民を あげて蚊の駆除に熱心に取り組んでいた様子がうかがえ る。このような取組や, 全般的な衛生レベルの向上, 日本 脳炎の予防接種の実施等により, 日本国内で蚊が媒介する 感染症に罹患する人の数は着実に減少していった。

\section{2. 感染症法に基づく蚊媒介感染症対策}

このような状況の中, 鳥インフルエンザ $\mathrm{H} 5 \mathrm{~N} 1$ 等の新 興・再興感染症の出現や医療体制の進歩など, 感染症を取 り巻く環境の変化に適応するため, 1999 年, 伝染病予防 法に代わり，新たに感染症法が制定されたわけであるが, 感染症法に押いては, 既知の感染症法を感染力や罹患した 場合の重篤性に基づいて分類し, それぞれについて法的に 取り得る措置を規定している。感染症法制定当時, 蚊媒介 感染症としては, デング熱, 日本脳炎, マラリアが (旧) 四類感染症として指定され, 医師がこれらの患者を診断し た場合は, 診断後 7 日以内に全ての患者を最寄りの保健所 に届け出るよう義務づけられていた。その後, 米国におい
て，ウエストナイル熱の流行が拡大したことを受け， 2002 年, 同疾病が (旧) 四類感染症に追加された。しかしなが ら,この（旧）四類感染症については, 患者を全数報告す ることにはなっていたが，媒介蚊の駆除等の対物措置につ いては何ら規定されて抢らず，仮にこれらの感染症が国内 で発生した場合，有効な対策を取ることができない恐れが あったことから， 2003 年に感染症法が改正された際，新 たな感染症の類型（新）四類感染症が創設された。蚊媒介 感染症を含む, 多くの動物由来感染症がこの（新）四類感 染症に分類され, 全例について医師に直ちに届け出ること が義務づけられたほか, 一例一例についての積極的疫学調 查や, 蚊の駆除等の対物措置が害施できることとなった。 この（新）四類感染症には, 現在, 黄熱やマラリアのほか, 約 10 種類の蚊媒介感染症が指定されているが, このうち, マラリア, デング熱, チクングニア熱については, 毎年, 海外の流行地で感染し, 帰国後国内で発症して診断される 症例（輸入症例）が継続的に報告されている。しかしなが ら, 国内での感染が認められる蚊媒介感染症は, 近年では 日本脳炎のみであり,これについてもワクチン接種により, 多いときでも年間 10 例程度の報告に押さえられてきてい た (表)。

また, 感染症法では, 感染症を媒介する恐れのある動物 が国内に持ち込まれることを未然に防ぐため，また， 万一, 輸入動物に起因する感染症が発生した場合, 追跡調 查等の実施を可能にするため, 全ての哺乳類と鳥類（家畜 伝染病予防法及び狂犬病予防法に基づいて検疫されている 動物を除く。）について, 輸入する際は, その都度, 厚生 労働大臣宛て輸入届け出を提出することを輸入者に義務付 けている。届出の際には, 輸出国政府機関により発行され, 当該動物がヒトに感染させる恐れのある感染症に罹患して いないことを確認した旨を示す衛生証明書（Health Certificate）を併せて提出する必要がある。衛生証明書で証明す べき事項は，動物の分類ごとに定められているが，蚊媒介 感染症に関しては, ウエストナイル熱の自然宿主である鳥 類について, 輸出前の一定期間, 蚊の侵入を防止するため の措置が講じられた検疫施設等で倸留され, ウエストナイ ル熱の臨床症状を示していないこと等が輸出国政府機関に より証明されなければ輸入できないこととなっている2。 このように, ペット等の動物の輸入に対して一定のハード ルが科されたことから, 動物輸入届出制度の創設以降, 動 物の輸入量は減少傾向にあり, 蚊媒介感染症を含めた動物 由来感染症のわが国への侵入防止に重要な役割を果たして いる。

2 動物の輸入届出制度 (http://www.mhlw.go.jp/bunya/kenkou/ kekkaku-kansenshou12/) 
表 主な蚊媒介感染症の届出状況

\begin{tabular}{|c|c|c|c|c|c|c|c|c|c|c|c|}
\hline & \multirow{2}{*}{$\begin{array}{c}\text { デング } \\
\text { 熱 }\end{array}$} & \multirow{2}{*}{$\begin{array}{c}\text { チクン } \\
\text { グニア } \\
\text { 熱 }\end{array}$} & \multirow{2}{*}{$\begin{array}{c}\text { 日本脳 } \\
\text { 炎 }\end{array}$} & \multirow{2}{*}{$\begin{array}{c}\text { ウエス } \\
\text { トナイ } \\
\text { ル熱 }\end{array}$} & \multirow{2}{*}{ 黄熱 } & \multicolumn{6}{|c|}{ マラリア } \\
\hline & & & & & & 三日熱 & 四日熱 & 卵形熱 & 熱帯熱 & 不明熱 & 合計 \\
\hline 2003 年 & 32 & $\cdots$ & 1 & 0 & 0 & 40 & 2 & 6 & 30 & 0 & 78 \\
\hline 2004 年 & 49 & $\cdots$ & 5 & 0 & 0 & 34 & 1 & 7 & 32 & 1 & 75 \\
\hline 2005 年 & 74 & $\cdots$ & 7 & 1 & 0 & 25 & 2 & 2 & 38 & 0 & 67 \\
\hline 2006 年 & 58 & $\cdots$ & 7 & 0 & 0 & 21 & 2 & 4 & 31 & 4 & 62 \\
\hline 2007 年 & 89 & $\cdots$ & 10 & 0 & 0 & 25 & 0 & 2 & 23 & 2 & 52 \\
\hline 2008 年 & 104 & $\cdots$ & 3 & 0 & 0 & 18 & 1 & 1 & 35 & 1 & 56 \\
\hline 2009 年 & 93 & $\cdots$ & 3 & 0 & 0 & 14 & 0 & 1 & 37 & 4 & 56 \\
\hline 2010 年 & 244 & $\cdots$ & 4 & 0 & 0 & 22 & 1 & 5 & 42 & 4 & 74 \\
\hline 2011 年 & 113 & 10 & 9 & 0 & 0 & 29 & 3 & 1 & 44 & 1 & 78 \\
\hline 2012 年 & 221 & 10 & 2 & 0 & 0 & 19 & 2 & 4 & 40 & 7 & 72 \\
\hline 2013 年 & 249 & 14 & 9 & 0 & 0 & 7 & 2 & 2 & 29 & 7 & 47 \\
\hline 2014 年* & $340 * *$ & 16 & 2 & 0 & 0 & 11 & 0 & 4 & 41 & 4 & 60 \\
\hline
\end{tabular}

*2014 年は速報值

** 国内感染症例 162 例を含む

\section{3. 検疫所での対応}

蚊媒介感染症については, 輸入症例として, 海外から人 が持ち込むだけではなく，媒介蚊そのものが国内に侵入し てくる恐れがある。このことから, 全国の空港 - 開港に設 置された厚生労働省の検疫所においては, 検疫法に基づき, 港湾内, 空港建物内, 航空機の客室・貨物室等の蚊族の調 査を行っているほか，港湾内に設置したトラップ等で捕獲 された蚊のウイルス保有調查や, 幼虫蚊・成虫蚊の防除等 の業務を担当している。このほか，海外への渡航者に対し て, 蚊媒介感染症等の流行状況について情報提供や注意喚 起を行うとともに, 帰国時に感染症への罹患が疑われる人 の検疫を実施することで, 蚊媒介感染症等の国内侵入 · 蔓 延を防止するとともに，日本には生息しない，外来媒介蚊 （例 : ネッタイシマカ）の侵入監視に努めている。

\section{4. 国内感染症例の発生と特定感染症予防指針}

2014 年 1 月, 2013 年 8 月下旬に日本を旅行したドイッ 人が，帰国後，デング熱を発症した事例が，ドイツのロベ ルト・コッホ研究所から報告された ${ }^{3}$ この事例については, 感染地の特定はできないものの，潜伏期間や，患者がドイ ツー日本の直行便で移動していること等の状況から勘案し て, 日本国内で感染した可能性は否定できないとの結論が

デテング熱について (http://www.mhlw.go.jp/bunya/kenkou/ kekkaku-kansenshou19/dengue_fever.html)
内外の専門家より得られている。デング熱については，ヒ トからヒトへの直接感染はないが，デングウイルスを媒介 し得るヒトスジシマカは，北海道と青森県を除く全国に分 布している。これまで国内で行われた捕集蚊のサーベイラ ンスに扔いて，デングウイルスが検出されたという報告は なかったが，デング熱の急性期の患者（輸入症例）を刺し たヒトスジシマカが，さらに周囲の人を刺すことにより， デング熱の散発事例が一過性に国内で発生するというシナ リオも起こり得ないことではない。このドイッの事例を受 けて，全国の医療機関等，関係者に対して，本件に関する 情報提供を行うとともに，デング熱の輸入症例があった場 合，さらなる国内感染例の発生を防ぐために，患者が蚊に 刺されないように注意すること，万一，患者家族等からデ ング熱を発症する者があった場合には，速やかに保健所へ 報告を行うよう依頼した。同時に, 厚生労働科学研究班に おいて，デング熱の国内感染症例が発生した際の疫学調査 の実地方法や媒介蚊対策に関する自治体向け手引きや臨床 医向けの診断ガイドラインの作成に着手した。このように, デング熱の国内感染事例発生に向けて準備を進める中, 2014 年 8 月 27 日, 日本国内では約 70 年ぶりとなるデン グ熱の国内感染事例が確認された。その後，都内の代々木 公園等を主な推定感染地とするデング熱の患者が相次いで 報告され，10月末までに約 160 名の患者が報告される事 態となった。厚生労働省では, 完成間近であった上記手引 きやガイドラインの暫定版を自治体や関係機関に直ちに配 布し, 適切な対応と協力を呼びかけるとともに, 9 月 6 日 
には東京都・ 23 特別区・関係機関の参加を得て, 緊急対 策会議を開催し，住民への注意喚起や患者への対応のあり 方等について協議を行った。また, 代々木公園を抱える渋 谷区とその隣接 6 区と連携し, 9 公園における蚊のウイル ス保有調查を実施したほか，19 区の担当者を対象に，蚊 の捕集法に関する講習会を実施した。また，デング熱の患 者を診断するための迅速診断キット（NS1 抗原検出キット） を全国の地方衛生研究所に配布するなどして, 診断体制を 整備した。

このような緊急的な対応の中で様々な課題が明らかと なったが, 蚊媒介感染症の蔓延防止のためには, (1)流行発 生時だけではなく, 平常時から媒介蚊対策を実施すること, (2)患者の的確な診断と適切な医療を提供すること, (3)患者 の発生動向を迅速に把握すること, (4)流行発生時に的確な 蚊対策を実施すること，が特に重要であると考えられた。 しかしながら, 既述したように, 近年では国内での蚊媒介 感染症の発生は皆無に近く, 伝染病予防法時代には普通に 行われていた媒介蚊対策を行うことも希となり，行政機関 においても，国民の間においても，蚊対策の知識・経験が 失われつつあるという問題が浮き彫りとなった。

このような問題を解決するためには, 蚊媒介感染症対策 の充実が契緊の課題であると考えられたことから，厚生労 働省では, 感染症法第 11 条の規定に基づき, 蚊媒介感染 症を特に総合的に予防対策に取り組むべき感染症に位置づ け，予防の総合的な推進を図るための指針「蚊媒介感染症 に関する特定感染症予防指針」を策定することとした。こ の指針は, 厚生科学審議会感染症部会において取りまとめ られ，パブリックコメントの手続きを経た後, 4 月 28 日 に告示された。この指針では, 国, 都道府県, 市町村, 医
師・医療機関といった全ての関係者が，デング熱等の蚊媒 介感染症の国内感染症例発生時だけではなく, 平常時の予 防対策においても，それぞれの役割を果たすことで，蚊媒 介感染症の発生・蔓延を予防していくことを目指してい る。国民に対しても，蚊媒介感染症に関する知識をしっか り持ち, 蚊に刺されないための防蚊対策を行うなど，積極 的な役割を果たすよう求めている。

\section{5. リスクコミュニケーション}

蚊媒介感染症に関する特定感染症予防指針においては, 国民の果たす役割の重要性が繰り返し強調されているが, 国民の一人一人に蚊媒介感染症について正しい知識を持っ ていただくために, 厚生労働省では, ポスターやリーフレッ ト，ハンドブックなどを活用したリスクコミュニケーショ ンにも力を注いでいる。デング熱やチクングニア熱等の蚊 媒介感染症については, まず, 海外の流行地域でこれらの 感染症に罹患して帰国する方の数を減らすことが, 国内発 生のリスクを低減する上で重要であるが, 厚生労働省では, 検疫所のホームページ FORTH (For Travelers' Health ; www. forth.go.jp）において, 海外における感染症の最新の発生 状況について注意喚起を行っているほか, 黄熱の予防接種 に関する案内など, 渡航者に必要とされる情報を夕イム リーに提供している。特に多くの日本人が海外旅行に出か ける年末 ・年始や $\mathrm{GW}$, 夏休み等の長期休暇の時期には, 旅行者の皆さんが安全で快適に旅行し, 帰国することがで きるよう, 海外では多く発生しているが, 日本国内ではあ まり知られていない感染症について情報提供を行うととも に, 感染症を媒介する蚊やマダニ類に刺されない工夫など, 具体的な予防方法について，ホームページや Twitter 等を

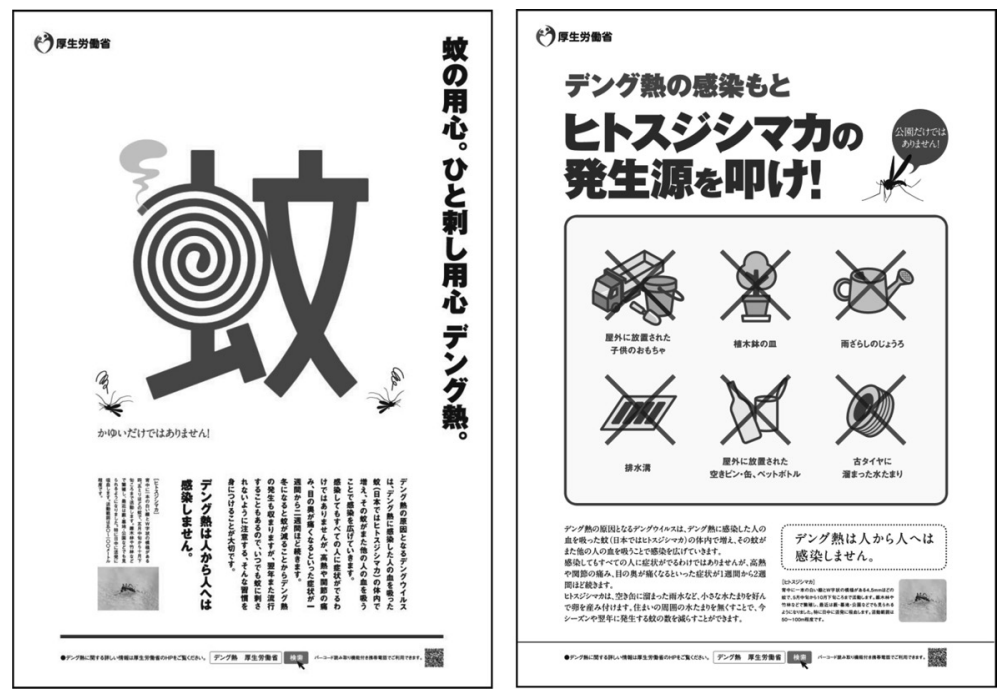

図蚊に関する注意喚起ポスター 
通じてアドバイスを行っている。また，国内においても， 媒介蚊をコントロールするためには, 国民の皆さん一人一 人の地道な取組と協力が不可欠であることから, ポスター の配布等を通じて, 住居周りの環境整備に努め, 蚊の発生 源を減らすとともに, 蚊に刺されないよう, 注意喚起を行っ ている(図)。

\section{おわりに}

昨年の夏に発生したデング熱の国内感染事例は, 国内外 から多くの人が訪れる大規模公園が主な感染地であったた
め, 確認された患者数も多く，また，デング熱がほとんど の国民にとっては，なじみの薄い感染症であったため，大 きな注目を集めることとなった。ここまでの規模に至らず とも, 小さなアウトブレイクはこれまでにも国内で起きて いた可能性はあるし，国際的な人の往来がますます盛んに なりつつある昨今, これからも起こり得るものと考え, 行 政機関，医療機関，そして国民一人一人が，それぞれの役 割を積極的に果たし，一丸となって対策にあたることが求 められている。 